\title{
Intravenous Immunoglobulin Modulates Human Mononuclear Phagocyte Tumor Necrosis Factor- $\alpha$ Production In Vitro
}

\author{
TONI DARVILLE, DALE TABOR, KIM SIMPSON, AND RICHARD F. JACOBS
}

Arkansas Children's Hospital and the University of Arkansas for Medical Sciences, Little Rock, Arkansas 72202-3591

\begin{abstract}
Mononuclear phagocytes (MO) secrete tumor necrosis factor- $\alpha$ (TNF) in response to inflammatory stimuli, most notably the bacterial product lipopolysaccharide (LPS). Cross-linking of MO Fc receptors also induces TNF release. Immunoglobulin for i.v. use is currently being investigated for the treatment and prophylaxis of neonatal sepsis and for the treatment of various syndromes of autoimmune dysfunction in children and adults. We examined the in vitro effect of immunoglobulin- $\gamma$ (IgG) on neonatal (cord blood) monocyte and adult MO TNF production. Kinetic studies were performed on MO incubated with IgG alone and on MO preincubated with IgG and stimulated with interferon- $\gamma / \mathrm{LPS}$. Incubation of MO in IgG (1-25 g/ L) for 2, 6, and $24 \mathrm{~h}$ did not stimulate TNF secretion or production. However, enhanced TNF secretion was detected in MO preincubated in IgG and subsequently stimulated with interferon- $\gamma /$ LPS. TNF secretion by cord blood monocytes was increasingly enhanced by preincubation for $6 \mathrm{~h}$ with 1,10 , and $25 \mathrm{~g} / \mathrm{L} \mathrm{IgG}(2413.1 \pm 1389.4, p<0.05$; 4070.4 $\pm 3069.2, p<0.005$; and 6383.7 \pm 2982.2, $p<$ 0.005 versus $1215 \pm 575.9 \mathrm{ng} / \mathrm{L}$, respectively, in cells preincubated in medium alone). Significant enhancement was also detected in cord blood monocytes preincubated in IgG for 2 h. TNF secretion by adult MO was similarly enhanced $(6082.0 \pm 1732.8, p<0.05 ; 7158.8 \pm 3938.2, p$ $<0.05$; and $7302.7 \pm 3451.4, p<0.05$ versus $3353.2 \pm$ $2946.7 \mathrm{ng} / \mathrm{L}$ for 1,10 , and $25 \mathrm{~g} / \mathrm{L} \mathrm{IgG}$, respectively, versus preincubation in medium alone). In additional experiments performed with $F c$, Fab, and $F\left(a^{\prime}\right)_{2}$ fragments, only $\mathrm{F}\left(\mathrm{ab}^{\prime}\right)_{2}$ fragments yielded positive results. Northern analyses revealed increased levels of mRNA for TNF only when $25 \mathrm{~g} / \mathrm{L}$ IgG were used for preincubation. Preincubation in the lower concentrations of IgG did not result in increased accumulations of TNF mRNA. Thus, IgG acts primarily posttranscriptionally to enhance interferon- $\gamma /$ LPS-induced TNF release in vitro. (Pediatr Res 35: 397403, 1994)
\end{abstract}

\section{Abbreviations}

MO, mononuclear phagocyte

TNF, tumor necrosis factor- $\alpha$

LPS, lipopolysaccharide

IVIG, immunoglobulin for i.v. use

Received July 19, 1993; accepted December 2, 1993.

Correspondence: Toni Darville, M.D., Pediatric Infectious Diseases, Arkansas Children's Hospital \& University of Arkansas for Medical Sciences, 800 Marshall St., Little Rock, AR 72202-3591.

Supported by a Pediatric Infectious Diseases Society Fellowship Award provided by Bristol-Meyers Squibb Company, by the University of Arkansas for Medical Sciences MCPG/CUMG Research Development Fund, and by a donation from Rosalyn and Harry Hastings.

'Presented in part at the 1993 annual meeting of the Society for Pediatric Research, Washington, DC.
CBMO, cord blood monocyte

IFN- $\boldsymbol{\gamma}$, interferon- $\boldsymbol{\gamma}$

TNF/cachectin constitutes one of the major inflammatory mediators secreted by activated monocytes and macrophages (1) it is implicated as a primary and proximal mediator of endotoxic shock (2) and plays a physiologic role in inflammation. Receptors for the Fc domain of immunoglobulins are involved in the regulation of various monocyte/macrophage immune functions, including phagocytosis (3), antibody-dependent cell-mediated cytotoxicity (4), the clearance of immune complexes (5), and the secretion of inflammatory mediators (6). Among the secretory products induced by $\mathrm{Fc}$ interactions are leukotrienes (7), prostaglandins (8), various hydrolytic enzymes (9), and multiple cytokines, including IL-1 (10), IL-6 (11), and TNF (12). Debets et al. (12) showed that when monocyte Fc receptors bound with cytophilic human IgG were cross-linked by the addition of antihuman IgG, rapid secretion of TNF was induced. These experiments were conducted with adherent adult human monocytes; soluble IgG alone failed to induce a response. In subsequent work, Debets et al. (13) demonstrated that cross-linking of FcR was not sufficient for the induction of TNF but that high affinity $\mathrm{Fc}-\mathrm{FcR}$ interactions are required.

Kuhnert et al. (14) demonstrated the induction of TNF and IL-1 secretion by adult human mononuclear cells cultured in suspension in the presence of soluble IgG and $10 \%$ autologous serum. Moreover, suspension cultures of mononuclear cells exposed to $\mathrm{IgG}$ were primed for enhanced production of TNF and IL-1 upon subsequent stimulation with LPS. Although $F\left(a b^{\prime}\right)_{2}$ fragments exhibited priming capacity similar to intact IgG, they were unable to induce cytokine secretion by themselves, again suggesting that the Fc portion of IgG is important in inducing a cytokine response.

Multiple clinical trials have evaluated IVIG as adjunctive therapy for neonatal sepsis (15-19), and although the results suggest benefit, the small numbers of patients studied prevent any conclusions regarding efficacy. IVIG is also being investigated for the prophylaxis of neonatal sepsis (20-26). These studies have not revealed any significant toxic effects associated with IVIG administration. Because of the potential for IgG-FcR interactions to occur in vivo when IVIG is administered, we sought to examine the in vitro effects of IVIG on neonatal MO TNF production. Studies have shown that neonatal monocytes are as competent as adult monocytes in the processing and presentation of antigen (27) and phagocytosis and killing of bacteria (28). However, certain functions are diminished compared with adults, such as chemotaxis $(29,30)$ and antibodydependent cellular cytotoxicity to herpes simplex virus (31). Kohl et al. (31) found decreased expression of the high-affinity IgG FcR on neonatal mononuclear cells and proposed that defective 
FcR expression may partly explain low neonatal mononuclear cell antibody-dependent cellular cytotoxicity. To determine whether the regulatory effects of IVIG regarding MO TNF production are specific to neonates, we paralleled select experiments in adult MO. In initial experiments, we examined the ability of soluble human IgG, in the form of IVIG, to induce TNF production. We then investigated the immunomodulating effects of IVIG by examining its effect on the MO TNF response induced by the known stimulants IFN- $\gamma$ and LPS.

\section{MATERIALS AND METHODS}

Cell isolation and culture. Blood samples were obtained from the umbilical cords of normal, full-term, nonstressed neonates by using sterile blood collection tubes containing dry $\mathrm{Na}_{2}$-EDTA or from healthy adult volunteers by using sterile heparinized syringes $\left(10^{3} \mathrm{U}\right.$ heparin/L blood). After collection, the blood was diluted 1:1 with sterile PBS. The cell suspension was overlaid on Histopaque 1077 (Sigma Chemical Co., St. Louis, MO) and the mononuclear cells were separated by density-gradient centrifugation. These cells were washed once with sterile PBS and then incubated for $10 \mathrm{~min}$ at $37^{\circ} \mathrm{C}$ in $0.01 \mathrm{M}$ Tris- $0.83 \% \mathrm{NH}_{4} \mathrm{Cl}(\mathrm{pH}$ 7.2-7.4) to lyse contaminating red blood cells. After centrifugation, cells were washed twice more with sterile PBS before they were resuspended in RPMI 1640 (GIBCO, Grand Island, NY) containing $2 \mathrm{mM}$ L-glutamine, $10^{4} \mathrm{U} / \mathrm{L}$ penicillin $\mathrm{G}, 10^{4} \mu \mathrm{g} / \mathrm{L}$ streptomycin, and $10 \%$ pooled heat-inactivated human type $A B$ serum (kindly provided by the local blood bank). Enumerated cells were greater than $95 \%$ viable by trypan blue exclusion. Monocytes were isolated from mononuclear cells by adherence to plastic. For this purpose, $1 \times 10^{5}$ mononuclear cells were allowed to adhere 1.5 to $2 \mathrm{~h}$ at $37^{\circ} \mathrm{C}$ in $0.3 \mathrm{~mL}$ medium/well in 96-well flat-bottomed tissue culture trays (Costar, Cambridge, MA). When cells were prepared for RNA isolation, monolayers were established in $100 \times 20-\mathrm{mm}$ tissue culture dishes (Becton Dickinson, Franklin Lakes, NJ). All other conditions were the same. Nonadherent cells were removed by washing five times with warm sterile PBS, and fresh culture medium was added. Monolayers were then cultured for $5 \mathrm{~d}$ at $37^{\circ} \mathrm{C}$ in $5 \% \mathrm{CO}_{2}$, before experimentation. The adherent cell population consisted of more than $90 \%$ monocytes, as determined by staining with $\alpha$-naphthyl esterase (Sigma Diagnostics, St. Louis, MO). Cultures of adherent cells were monitored periodically by inverted microscopy; monocytes routinely took on morphologic characteristics of macrophages after $5 \mathrm{~d}$ in culture. All reagents had undetectable levels of endotoxin, as verified by the Limulus amebocyte assay (Cape Cod Association, Woods Hole, MA) (sensitivity of $20 \mathrm{ng} / \mathrm{L}$ ).

Production of TNF. After $5 \mathrm{~d}$ in culture, monocyte-derived macrophages were replated with culture medium alone or with culture medium containing one of the following: pooled human IgG for i.v. infusion (Gammagard, Baxter-Healthcare Corp., Glendale, CA) in concentrations of $6.3 \times 10^{-6} \mathrm{M}, 6.3 \times 10^{-5} \mathrm{M}$, or $1.6 \times 10^{-4} \mathrm{M}(1,10$, or $25 \mathrm{~g} / \mathrm{L}$, respectively); human $\mathrm{IgG}$ $\mathrm{F}\left(\mathrm{ab}^{\prime}\right)_{2}$ fragments in concentrations of $9.1 \times 10^{-7} \mathrm{M}$ or $9.1 \times$ $10^{-6} \mathrm{M}(0.1 \mathrm{~g} / \mathrm{L}$ or $1 \mathrm{~g} / \mathrm{L})$; human IgG Fab fragments in concentrations of $2.0 \times 10^{-6} \mathrm{M}$ or $2.0 \times 10^{-5} \mathrm{M}(0.1 \mathrm{~g} / \mathrm{L}$ or $1 \mathrm{~g} / \mathrm{L})$; or human Fc pieces in concentrations of $3.7 \times 10^{-4} \mathrm{M}$ or $3.7 \times$ $10^{-3} \mathrm{M}(0.1 \mathrm{~g} / \mathrm{L}$, or $1 \mathrm{~g} / \mathrm{L})$. All IgG fragments were obtained from Jackson ImmunoResearch Laboratories, West Grove, PA. Monolayers were incubated for 2,6 , or $24 \mathrm{~h}$ at $37^{\circ} \mathrm{C}$ in $5 \% \mathrm{CO}_{2}$. In early experiments, 50 or $100 \mathrm{~g} / \mathrm{L}$ of $\mathrm{IgG}$ were also used. Monolayer cell counts revealed that such high concentrations of IgG induced significant cell loss (85-95\% compared with 40$75 \%$ loss of cells incubated in lower concentrations of $\mathrm{IgG}$ ). After incubation, the plates were centrifuged at $300 \times g$ for $5 \mathrm{~min}$ and the cell-free supernatants were harvested from each well. Supernatants from each of three wells that had been treated the same were pooled and stored at $-70^{\circ} \mathrm{C}$ until used for the TNF assays.

In a second series of experiments, monolayers were treated as above; after this initial incubation in medium or medium with
IgG or IgG fragments, supernatants were removed, and $0.25 \mathrm{~mL}$ of either culture medium or culture medium with $10^{5} \mathrm{U} / \mathrm{L}(100$ $\mathrm{U} / \mathrm{mL}$ ) of human IFN- $\gamma$ (Genzyme Corp., Cambridge, MA) and $1 \mathrm{mg} / \mathrm{L}(1 \mu \mathrm{g} / \mathrm{mL})$ of Escherichia coli LPS (Sigma) were added to each well. After $3 \mathrm{~h}$ of incubation at $37^{\circ} \mathrm{C}$ in $5 \% \mathrm{CO}_{2}$, plates were centrifuged at $300 \times g$ for $5 \mathrm{~min}$, and the cell-free supernatants were harvested and stored at $-70^{\circ} \mathrm{C}$ until used for the TNF assays. Additional experiments performed in this series used lower concentrations of IgG: $6.3 \times 10^{-8} \mathrm{M}(0.01 \mathrm{~g} / \mathrm{L})$ or $6.3 \times 10^{-7} \mathrm{M}(0.1 \mathrm{~g} / \mathrm{L})$.

In an additional series of experiments, CBMO were incubated for $3 \mathrm{~h}$ in IFN- $\gamma\left(10^{5} \mathrm{U} / \mathrm{L}\right)$ and LPS $(1 \mathrm{mg} / \mathrm{L})$ or in IFN- $\gamma / \mathrm{LPS}$ and $\operatorname{IgG}(1,10$, or $25 \mathrm{~g} / \mathrm{L})$ simultaneously. After a 3-h incubation at $37^{\circ} \mathrm{C}$ in $5 \% \mathrm{CO}_{2}$, plates were centrifuged at $300 \times g$ for $5 \mathrm{~min}$, and the cell-free supernatants were harvested and stored at $-70^{\circ} \mathrm{C}$ until analyzed for TNF by ELISA.

In a final series of experiments, monolayers were incubated in IFN- $\gamma\left(10^{5} \mathrm{U} / \mathrm{L}\right) / \mathrm{LPS}(1 \mathrm{mg} / \mathrm{L})$ overnight $(18 \mathrm{~h})$, and after centrifugation, the cell-free supernatants were harvested for TNF assays. These cells were then replated with media alone or media with $\mathrm{IgG}$ in a concentration of $10 \mathrm{~g} / \mathrm{L}$ and incubated for $6 \mathrm{~h}$ at $37^{\circ} \mathrm{C}$ in $5 \% \mathrm{CO}_{2}$. After incubation, supernatants were harvested and stored at $-70^{\circ} \mathrm{C}$ until analyzed for TNF by ELISA.

Cell counts were made of each group using the pronasecetrimide procedure for counting cell nuclei (32). Briefly, to count cells, $0.5 \mathrm{~mL}$ of freshly filtered dilute pronase (Sigma) was equally divided among the three wells of a group, mixed, and allowed to incubate for $15 \mathrm{~min}$ at $37^{\circ} \mathrm{C}$. After this incubation, the pronase suspension was pulled from the wells and put into $12.5 \mathrm{~mL}$ of filtered cetrimide (Sigma) solution in an Accuvette II vial (Coulter, Hialeah, FL). The suspension of cell nuclei was then promptly counted in an electronic particle counter (Coulter).

TNF bioassay. TNF activity was determined by using an adaptation of the lytic assay of Carswell et al. (33) as modified by Aggarwal et al. (34). Briefly, mouse L929 fibroblast cells were plated in 96-well plates at a concentration of $4 \times 10^{4}$ cells/well. After an overnight incubation, supernatants were added to the plates and serially diluted in horizontal rows. To determine the specificity of the assay, appropriate dilutions of selected supernatants or standard human recombinant TNF (sp act $5 \times 10^{7}$ $\mathrm{U} / \mathrm{mg}$ ) (Genentech, South San Francisco, CA) were preincubated with 5 neutralizing $U$ of TNF MAb (sp act $6 \times 10^{6}$ neutralizing $\mathrm{U} / \mathrm{mg}$ ) (Genentech) for $4 \mathrm{~h}$ at $4^{\circ} \mathrm{C}$ before addition to the plates. Actinomycin D ( $8 \mathrm{mg} / \mathrm{L})$ (Sigma) was added to each well and plates were incubated overnight. After overnight incubation, samples were removed and plates washed with warm PBS to remove dead cells. The plates were stained with $0.05 \%$ crystal violet in $20 \%$ ethanol for $10 \mathrm{~min}$. Plates were then washed with cold tap water and allowed to dry for $24 \mathrm{~h}$. After drying, stain was eluted with $100 \mu \mathrm{L}$ of $100 \%$ methanol per well. Plates were read within $10 \mathrm{~min}$ of methanol addition at $562 \mathrm{~nm}$ on a microplate reader. OD of L929 cells incubated with medium alone represented $0 \%$ lysis, and cells treated with $3 \mathrm{M}$ guanidine hydrochloride represented $100 \%$ lysis. One unit of TNF is defined as that amount of TNF required to produce $50 \%$ lysis. Lysis was normalized to a standard of human recombinant TNF. The lower limit of detectability was $50 \mathrm{ng} / \mathrm{L}(2.5 \mathrm{U} / \mathrm{mL})$.

$T N F-E L I S A$. TNF concentrations of cell-free supernatants were determined with a TNF-specific ELISA kit (Genzyme) according to the manufacturer's instructions. The lower limit of detectability for this assay is $10 \mathrm{ng} / \mathrm{L}$.

$R N A$ isolation and Northern blot analysis. At the indicated times, total cellular RNA was isolated by the guanidium isothiocyanate- $\mathrm{CsCl}$ method (35). Total RNA samples were electrophoresed in $1.2 \%$ agarose/formaldehyde gels, and the integrity of the RNA was confirmed by ethidium bromide staining. After electrophoresis, RNA was transferred overnight to Hybond-N filters (Amersham, Arlington Heights, IL), baked at $80^{\circ} \mathrm{C}$ for 2 $\mathrm{h}$, and prehybridized for $18 \mathrm{~h}$ at $42^{\circ} \mathrm{C}$ in $50 \%$ formamide, $5 \times$ 
sodium chloride, sodium citrate (SSC), $1 \times$ Denhardt's, $50 \mathrm{mM}$ sodium phosphate ( $\mathrm{pH} 6.5$ ), $0.1 \%$ SDS, $0.250 \mathrm{~g} / \mathrm{L}$ salmon sperm DNA, and $10 \%$ dextran sulfate. Blots were hybridized for $18 \mathrm{~h}$ in the same buffer containing $10^{6} \mathrm{cpm} / \mathrm{mL}$ of $\mathrm{cDNA}$ probe. The probes used were a human TNF cDNA fragment, the 800 -bp $E c o$ RI cDNA fragment (36), and a 2-kb human $\beta$-actin cDNA (Clontech, Palo Alto, CA) that were randomly labeled (Boehringer Mannheim Corp., Indianapolis, IN) overnight at $25^{\circ} \mathrm{C}$; unincorporated nucleotides were removed by push column (Stratagene Cloning Systems, La Jolla, CA). After hybridization, blots were washed once with $2 \times \mathrm{SSC}, 0.1 \% \mathrm{SDS}$ for $30 \mathrm{~min}$ at $25^{\circ} \mathrm{C}$, followed by two washes with $0.1 \times$ SSC, $0.1 \%$ SDS for $20 \mathrm{~min}$ at $55^{\circ} \mathrm{C}$, and exposed to Kodak XAR-5 film at $-70^{\circ} \mathrm{C}$ with intensifying screens. For RNA quantification, filters were dehybridized and then rehybridized with the $\beta$-actin probe and exposed for $5 \mathrm{~d}$. Stripping was confirmed in each case by autoradiography before a second probe was used. Multiple autoradiographic exposures of multiple blots were quantitated by scanning on a laser densitometer (Hoefer Scientific Instruments, San Francisco, CA). Calculated ratios of TNF to $\beta$-actin mRNA levels were used for comparisons within groups.

Statistics. The two-sample $t$ test for unpaired data was used for statistical analysis. Differences were considered significant at the two-tailed $p<0.05$ level.

\section{RESULTS}

Evaluation of TNF response in adherent $M O$ exposed to IgG. Adherent CBMO were exposed to increasing concentrations of IgG, and at specific time intervals (2, 6, and $24 \mathrm{~h}$ ) supernatants were harvested and examined by ELISA for TNF. As shown in Table 1 , incubation in concentrations of IgG from $6.3 \times 10^{-6} \mathrm{M}$ to $1.6 \times 10^{-4} \mathrm{M}(1-25 \mathrm{~g} / \mathrm{L})$ for $6 \mathrm{~h}$ did not induce secretion of TNF more than adherence alone. Although low levels of TNF were detected in the supernatants of some of the cultures, the majority had levels that were barely detectable. Comparable results were seen in monolayers incubated for 2 and 24 h (data not shown).

Northern blot analysis of MO RNA levels paralleled these results. Depicted in Figure 1 is a representative autoradiogram from CBMO preparations. After $5 \mathrm{~d}$ in culture, a subsequent 6 $h$ incubation in medium alone, $6.3 \times 10^{-6} \mathrm{M} \mathrm{IgG}$, or $6.3 \times 10^{-5}$ $\mathrm{M}(1$ or $10 \mathrm{~g} / \mathrm{L}) \mathrm{IgG}$ resulted in similar accumulations of TNF mRNA. Bands were quantitated by densitometry, and when ratios of TNF mRNA to $\beta$-actin were compared, no alteration in the levels of TNF message was found. Incubation in concentrations of $1.6 \times 10^{-4} \mathrm{M}(25 \mathrm{~g} / \mathrm{L}) \mathrm{IgG}$ also had no effect (data not shown). These data indicate that soluble $\mathrm{IgG}$ alone does not induce significant production of TNF by adherent CBMO.

To determine whether a lack of response in our system was specific for neonatal MO, we analyzed supernatants from adult MO monolayers incubated with IgG. Again, we found that soluble IgG was unable to induce secretion of TNF greater than that caused by adherence (Table 1 ).

Effect of IgG on MOIFN-r/LPS-induced TNF response. We investigated the immunomodulating effects of IVIG by examin-

Table 1. TNF secretion by CBMO and adult monocytes exposed to $\operatorname{Ig} G^{*}$

\begin{tabular}{lll}
\hline & \multicolumn{2}{c}{$\mathrm{TNF}(\mathrm{ng} / \mathrm{L})$} \\
\cline { 2 - 3 } \multicolumn{1}{c}{ Cultured in } & CBMO, 6 h & Adult MO,6 h \\
\hline Medium only & $35.2 \pm 20.7$ & $72.8 \pm 131.2$ \\
$6.3 \times 10^{-6}(1 \mathrm{~g} / \mathrm{L}) \mathrm{IgG}$ & $12.8 \pm 17.4$ & $15.3 \pm 37.4$ \\
$6.3 \times 10^{-5} \mathrm{M}(10 \mathrm{~g} / \mathrm{L}) \mathrm{IgG}$ & $99.9 \pm 179.8$ & $88.6 \pm 158.4$ \\
$1.6 \times 10^{-4} \mathrm{M}(25 \mathrm{~g} / \mathrm{L}) \mathrm{IgG}$ & $91.8 \pm 192.3$ & $88.4 \pm 23.6$ \\
\hline
\end{tabular}

* Monocytes isolated as described in Materials and Methods were incubated with 1,10 , or $25 \mathrm{~g} / \mathrm{L} \mathrm{IgG}$. After a 6-h incubation period, TNF concentration in the supernatant was determined by ELISA. Results are means \pm SD of 10 experiments each.

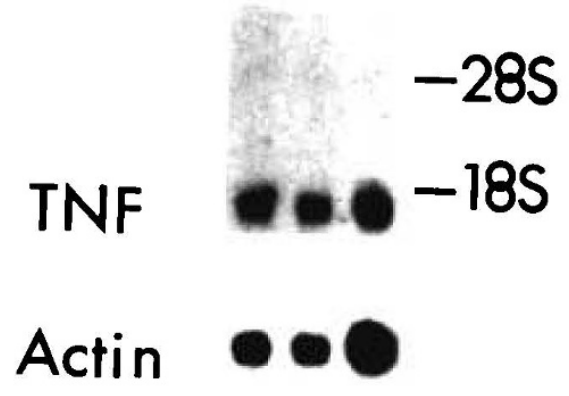

Fig. 1. Northern blot analysis of CBMO RNA. CBMO were prepared as described in Materials and Methods. Total RNA was extracted and electrophoresed after a 6-h incubation in medium alone (lane 1 ), medium and $1 \mathrm{~g} / \mathrm{L} \mathrm{lgG}$ (lane 2), or medium and $10 \mathrm{~g} / \mathrm{L} \mathrm{IgG} \mathrm{(lane} \mathrm{3).} \mathrm{All} \mathrm{exposure}$ times were the same.

ing its effect on the MO TNF response induced by IFN- $\gamma / \mathrm{LPS}$. Preincubation of CBMO in 1,10 , or $25 \mathrm{~g} / \mathrm{L} \mathrm{IgG}$ for 2 or $6 \mathrm{~h}$ caused enhanced secretion of TNF upon subsequent stimulation (Table 2). Despite the considerable subject-to-subject variation, the trend for enhancement was consistent. A 6-h preincubation with $25 \mathrm{~g} / \mathrm{L} \mathrm{IgG}$ resulted in the greatest enhancement of TNF secretion ( $\sim 5$-fold, compared with a 3 -fold increase at $2 \mathrm{~h}$ and only a 2-fold increase when monolayers were preincubated with IgG for $24 \mathrm{~h}$ ). This decline in enhancement with the 24-h preincubation was not caused by increased cell loss; cell loss varied from 40 to $75 \%$ for all three preincubation times as determined by monolayer cell counts. In addition, the time of preincubation did not significantly alter the TNF secretion detected in those cells pretreated with medium alone, in which cell loss also varied between 40 and $75 \%$. In preliminary experiments, concentrations of $50 \mathrm{~g} / \mathrm{L} \mathrm{IgG}$ and greater led to a marked decrease in TNF secretion, yet this concentration resulted in $>80 \%$ cell loss. Therefore, $25 \mathrm{~g} / \mathrm{L} \mathrm{IgG}$ became the maximum concentration used in our experiments.

Preincubation of adult MO with IgG for $6 \mathrm{~h}$ before stimulation with IFN- $\gamma /$ LPS also resulted in enhanced secretion of TNF (Table 2). Compared with CBMO, adult MO preincubated in medium alone produced significantly greater amounts of TNF upon stimulation with IFN- $\gamma /$ LPS $(3353.2 \pm 2946.7$ versus $1215.0 \pm 575.9 \mathrm{ng} / \mathrm{L}$ ). Therefore, the relative increase in TNF production by adult MO preincubated with IgG was less than that of CBMO ( 2-fold increase in adult MO, compared with $\sim 5$-fold increase in CBMO). Concentrations of 10 and $25 \mathrm{~g} / \mathrm{L}$ IgG were able to induce CBMO to secrete levels of TNF approaching those detected with adult $\mathrm{MO}$ (4070.4 \pm 3069.2 versus $7158.8 \pm 3938.2 \mathrm{ng} / \mathrm{L}$ and $6383.7 \pm 2982.2$ versus $7302.7 \pm$ $3451.4 \mathrm{ng} / \mathrm{L}$, for 10 and $25 \mathrm{~g} / \mathrm{L}$, respectively, in CBMO versus adult $\mathrm{MO}$ ).

Results of an L929 cytotoxicity assay on supernatants from CBMO preincubated for 2 and $6 \mathrm{~h}$ with $\operatorname{IgG}(1-25 \mathrm{~g} / \mathrm{L})$ confirmed the enhancement of TNF secretion and indicated that the TNF was functional (Table 3). Once again, preincubation with $25 \mathrm{~g} / \mathrm{L} \mathrm{IgG}$ for $6 \mathrm{~h}$ resulted in the greatest secretion of TNF upon subsequent stimulation with IFN- $\gamma /$ LPS.

To explore the dose-response paradigm more completely, we performed experiments with CBMO using the lower concentrations of $6.3 \times 10^{-8} \mathrm{M}(0.01 \mathrm{~g} / \mathrm{L})$ and $6.3 \times 10^{-7} \mathrm{M}(0.1 \mathrm{~g} / \mathrm{L}) \mathrm{IgG}$ for preincubation. Preincubation in these lower concentrations of IgG for 2 or $6 \mathrm{~h}$ did not enhance the TNF response seen upon subsequent stimulation with IFN- $\gamma /$ LPS (Table 3). Thus, the ability of IgG to enhance IFN- $\gamma /$ LPS-induced TNF secretion by $\mathrm{MO}$ in vitro is dose dependent with a threshold concentration $\left[6.3 \times 10^{-6} \mathrm{M}(1 \mathrm{~g} / \mathrm{L})\right]$ below which an enhanced response is not induced.

Northern analyses were performed on MO treated in the same manner to determine at what molecular level the TNF response was being increased. Depicted in Figure 2 is a representative 
Table 2. IgG modulation of IFN- $\gamma / L P S$-induced monocyte TNF secretion*

\begin{tabular}{llllc}
\hline & & \multicolumn{3}{c}{ TNF $(\mathrm{ng} / \mathrm{L})$} \\
\cline { 3 - 5 } & Pretreated with & 2-h Preincubation & 6-h Preincubation & 24-h Preincubation \\
\hline CBMO & Medium only & $1133.9 \pm 618.7$ & $1215.0 \pm 575.9$ & $1333.8 \pm 422.9$ \\
& $6.3 \times 10^{-6} \mathrm{M}(1 \mathrm{~g} / \mathrm{L}) \mathrm{IgG}$ & $2547.6 \pm 1217.7 \dagger$ & $2413.1 \pm 1389.4 \ddagger$ & $1788.1 \pm 816.3$ \\
& $6.3 \times 10^{-5} \mathrm{M}(10 \mathrm{~g} / \mathrm{L}) \mathrm{IgG}$ & $3542.6 \pm 3402.5 \ddagger$ & $4070.4 \pm 3069.2 \dagger$ & $2078.8 \pm 1254.8$ \\
& $1.6 \times 10^{-4} \mathrm{M}(25 \mathrm{~g} / \mathrm{L}) \mathrm{IgG}$ & $3733.5 \pm 2420.1 \dagger$ & $6383.7 \pm 2982.2 \dagger$ & $2724.0 \pm 1366.7 \dagger$ \\
Adult MO & Medium only & ND & $3353.2 \pm 2946.7$ & ND \\
& $6.3 \times 10^{-6} \mathrm{M}(1 \mathrm{~g} / \mathrm{L}) \mathrm{IgG}$ & $\mathrm{ND}$ & $6082.0 \pm 1732.8 \ddagger$ & ND \\
& $6.3 \times 10^{-5} \mathrm{M}(10 \mathrm{~g} / \mathrm{L}) \mathrm{IgG}$ & $\mathrm{ND}$ & $7158.8 \pm 3938.2 \ddagger$ & ND \\
& $1.6 \times 10^{-4} \mathrm{M}(25 \mathrm{~g} / \mathrm{L}) \mathrm{IgG}$ & $\mathrm{ND}$ & $7302.7 \pm 3451.4 \ddagger$ & ND \\
\hline
\end{tabular}

* Monocytes isolated as described in Materials and Methods were preincubated with 1, 10, or $25 \mathrm{~g} / \mathrm{L} \mathrm{IgG}$. After 2, 6, or $24 \mathrm{~h}$, monocytes were replated with IFN- $\gamma\left[10^{5} \mathrm{U} / \mathrm{L}(100 \mathrm{U} / \mathrm{mL})\right]$ and LPS $[1 \mathrm{mg} / \mathrm{L}(1 \mu \mathrm{g} / \mathrm{mL})]$. After a 3 -h incubation in these stimulants, TNF concentration in the supernatant was determined by ELISA. Results are means \pm SD of 10 experiments. ND, Not determined.

$+p<0.005$.

$\ddagger p<0.05$.

Table 3. L929 assay for TNF production by CBMO*

\begin{tabular}{lll}
\hline & \multicolumn{2}{c}{ TNF $\left(\times 10^{3} \mathrm{U} / \mathrm{L}\right)$} \\
\cline { 2 - 3 } \multicolumn{1}{c}{ Pretreated with } & \multicolumn{1}{c}{$\mathrm{CBMO}, 2 \mathrm{~h}$} & \multicolumn{1}{c}{$\mathrm{CBMO}, 6 \mathrm{~h}$} \\
\hline Medium only & $1503.0 \pm 872.7$ & $2072.0 \pm 1043.7$ \\
$6.3 \times 10^{-8} \mathrm{M}(0.01 \mathrm{~g} / \mathrm{L}) \mathrm{IgG}$ & $1460.3 \pm 823.0$ & $2269.9 \pm 1157.0$ \\
$6.3 \times 10^{-7} \mathrm{M}(0.1 \mathrm{~g} / \mathrm{L}) \mathrm{IgG}$ & $1962.0 \pm 1703.7$ & $2340.3 \pm 1164.4$ \\
$6.3 \times 10^{-6} \mathrm{M}(1 \mathrm{~g} / \mathrm{L}) \mathrm{IgG}$ & $4362.0 \pm 4137.6 \dagger$ & $5621.1 \pm 2862.0 \ddagger$ \\
$6.3 \times 10^{-5} \mathrm{M}(10 \mathrm{~g} / \mathrm{L}) \mathrm{IgG}$ & $4379.4 \pm 4521.5$ & $5431.2 \pm 3706.1 \dagger$ \\
$1.6 \times 10^{-4} \mathrm{M}(25 \mathrm{~g} / \mathrm{L}) \mathrm{IgG}$ & $5225.0 \pm 2164.1 \ddagger$ & $6084.3 \pm 4007.0 \dagger$ \\
\hline
\end{tabular}

* Monocytes isolated as described in Materials and Methods were preincubated with $1,10,25 \mathrm{~g} / \mathrm{L} \mathrm{IgG}$. After $2 \mathrm{~h}$ or $6 \mathrm{~h}$, monolayers were replated with IFN- $\gamma\left(10^{5} \mathrm{U} / \mathrm{L}\right)$ and $\mathrm{LPS}(1 \mathrm{mg} / \mathrm{L})$. After a 3-h incubation in these stimulants, TNF activity in the supernatant was determined by bioassay. Results are means \pm SD of 10 experiments.

$\dagger p<0.05$.

$\ddagger p<0.005$.

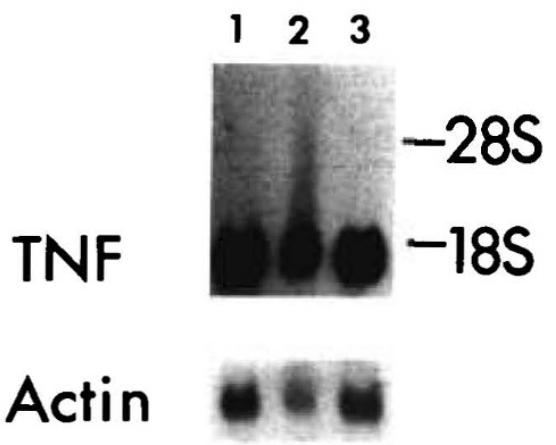

Fig. 2. Northern blot analysis of CBMO RNA. CBMO were prepared as described in Materials and Methods. After $6 \mathrm{~h}$ of preincubation in medium (lane 1), medium and $1 \mathrm{~g} / \mathrm{L} \mathrm{IgG} \mathrm{(lane} \mathrm{2),} \mathrm{or} \mathrm{medium} \mathrm{and} 10$ $\mathrm{g} / \mathrm{L}$ IgG (lane 3), CBMO were stimulated with IFN- $\gamma /$ LPS for $3 \mathrm{~h}$ and total RNA was extracted and electrophoresed. All exposure times were the same.

autoradiogram of TNF mRNA levels in CBMO preincubated for $6 \mathrm{~h}$ in medium alone or medium plus 1 or $10 \mathrm{~g} / \mathrm{L} \mathrm{IgG}$ and subsequently stimulated with IFN- $\gamma / \mathrm{LPS}$. When ratios of TNF mRNA to $\beta$-actin were compared, no alterations in the accumulations of TNF message were detected. Similar results were seen in cells preincubated for 2 and $24 \mathrm{~h}$ with these same concentrations of IgG (data not shown). But, when monolayers were preincubated in $25 \mathrm{~g} / \mathrm{L}$ of $\mathrm{IgG}$, increased accumulations of mRNA for TNF were seen (Fig. 3). TNF mRNA was detectable

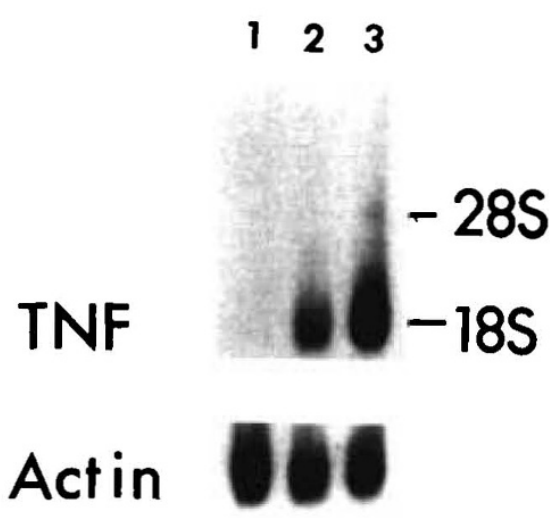

Fig. 3. Northern blot analysis of CBMO RNA. CBMO were prepared as described in Materials and Methods. Lane 1 represents CBMO cultured for $6 \mathrm{~h}$ in medium alone. Lane 2 represents CBMO preincubated in medium for $6 \mathrm{~h}$ and then stimulated with IFN- $\gamma / \mathrm{LPS}$ for $3 \mathrm{~h}$. Lane 3 represents CBMO preincubated in $25 \mathrm{~g} / \mathrm{L}$ IgG for $6 \mathrm{~h}$ and then stimulated with IFN- $\gamma / \mathrm{LPS}$ for $3 \mathrm{~h}$. All exposure times were the same.

in unstimulated monocytes, and the absolute amount varied between individuals (compare Fig. 1, lane 1 with Fig. 3, lane 1). IFN- $\gamma /$ LPS stimulation led to greatly increased accumulations of TNF mRNA. Preincubation of CBMO in $25 \mathrm{~g} / \mathrm{L} \mathrm{IgG}$ for $6 \mathrm{~h}$ increased the levels of TNF message induced by IFN- $\gamma /$ LPS by $\sim 2$-fold (by densitometry). Northern analyses performed with adult MO yielded similar results; increased levels of mRNA for TNF were detected only when the higher concentration of $25 \mathrm{~g} /$ L IgG was used for preincubation (data not shown).

We performed an additional set of experiments to examine the ability of IgG to potentiate an IFN- $\gamma / \mathrm{LPS}$-induced TNF response. CBMO were incubated in IFN- $\gamma /$ LPS for $18 \mathrm{~h}$, after which their supernatants were removed for TNF assay. A group of cells was replated in medium and a second group in $10 \mathrm{~g} / \mathrm{L}$ IgG. After a 6-h incubation, supernatants were again harvested for analysis. TNF secretion as detected by ELISA was $641.7 \pm$ $145.3 \mathrm{ng} / \mathrm{L}$ for cells incubated in IFN- $\gamma /$ LPS for $18 \mathrm{~h}$. When the cells were replated in medium for $6 \mathrm{~h}$, the amount of TNF detected decreased to $59.9 \pm 34.6 \mathrm{ng} / \mathrm{L}$, but in cells replated with $10 \mathrm{~g} / \mathrm{L}$ of $\mathrm{IgG}$ for $6 \mathrm{~h}$, the levels of TNF remained high $(602.2 \pm$ $243.7 \mathrm{ng} / \mathrm{L})$. Values are means \pm SD of 10 experiments each. Detection of TNF in the last group of cells indicates the ability of IgG to augment a prior stimulus for TNF release. Although these data support and confirm our earlier results, they do not increase our knowledge of the mechanism for this increased response. 
The potential exists for antibodies present in the IVIG to bind LPS, creating LPS/IgG immune complexes, which could act as a potent stimulus in vitro. We explored this possibility by adding IgG, IFN- $\gamma$, and LPS simultaneously. CBMO were incubated for $3 \mathrm{~h}$ in the stimulants IFN- $\gamma$ and LPS or in IFN- $\gamma / \mathrm{LPS}$ in combination with 1,10 , or $25 \mathrm{~g} / \mathrm{L} \mathrm{IgG}$. Although a trend toward increased TNF secretion was detected, the increases were not statistically significant $(1812 \pm 2362.0, p=0.72 ; 2087.5 \pm$ $1916.9, p=0.46 ;$ and $3260.9 \pm 4472.8, p=0.29$ in cells incubated in IFN- $\gamma / \mathrm{LPS}$ combined with 1,10 , or $25 \mathrm{~g} / \mathrm{L}$ of IgG, respectively, versus $1444.9 \pm 1489.4 \mathrm{ng} / \mathrm{L}$ in cells incubated in IFN- $\gamma /$ LPS alone). TNF levels were measured by ELISA $(n=8)$. IgGMO interaction causes increased TNF production in MO subsequently stimulated with IFN- $\gamma / \mathrm{LPS}$ or in MO previously exposed to these stimulants. However, if IgG-MO interactions occur simultaneously with IFN- $\gamma /$ LPS stimulation, no increase in TNF secretion is observed.

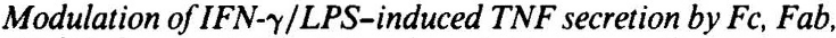
or $F\left(a b^{\prime}\right)_{2}$ fragments. To determine whether the entire molecule of $\mathrm{IgG}$ is required for regulation of TNF production, experiments were performed in which either $\mathrm{Fc}$, Fab, or $\mathrm{F}\left(\mathrm{ab} \mathrm{b}^{\prime}\right)_{2}$ fragments of human IgG were used for pireincubation. Preincubation of CBMO in Fc fragments in concentrations of $3.7 \times 10^{-4} \mathrm{M}(0.1$ $\mathrm{g} / \mathrm{L})$ or $3.7 \times 10^{-3} \mathrm{M}(1 \mathrm{~g} / \mathrm{L})$ or Fab fragments in concentrations of $2.0 \times 10^{-6} \mathrm{M}(0.1 \mathrm{~g} / \mathrm{L})$ or $2.0 \times 10^{-5} \mathrm{M}(1 \mathrm{~g} / \mathrm{L})$ for $6 \mathrm{~h} \mathrm{had}$ no effect on subsequent IFN- $\gamma / \mathrm{LPS}$-induced TNF secretion (Table 4). However, when CBMO were preincubated in $9.1 \times$ $10^{-7} \mathrm{M}(0.1 \mathrm{~g} / \mathrm{L})$ or $9.1 \times 10^{-6} \mathrm{M}(1 \mathrm{~g} / \mathrm{L}) \mathrm{F}\left(\mathrm{ab}^{\prime}\right)_{2}$ fragments, enhanced TNF secretion was detected. This enhancement was not as great as that previously seen with whole IgG molecules (maximum increase seen was $\sim 3$-fold) (Table 4). Experiments were also performed in which CBMO were incubated in these reagents without subsequent stimulation with IFN- $\gamma /$ LPS. Negligible amounts of TNF were induced by these reagents alone (data not shown).

\section{DISCUSSION}

In previous works by Kuhnert et al. (14), the addition of soluble IgG to human mononuclear cells in suspension induced the secretion of TNF and IL-1. In contrast, Debets et al. (12), found that solid-phase antibodies specific for binding Fc $\gamma \mathrm{RI}$ or Fc $\gamma$ RII induced TNF secretion by adherent human monocytes, whereas the same antibodies in the fluid phase failed to induce a response. An additional study by Shimozato et al. (37) demonstrated that i.v. infusion of IgG resulted in a reduction of TNF serum levels in rabbits subsequently given LPS and that IgG suppressed the production of TNF by rabbit macrophages stimulated in vitro with LPS.

Because of the widespread use of IVIG in our neonatal nur-

Table 4. Modulation of IFN- $\gamma / L P S$-induced CBMO TNF secretion by $F c$, $F a b$, and $F\left(a b^{\prime}\right)_{2}$ fragments ${ }^{*}$

\begin{tabular}{|c|c|}
\hline Pretreated with & $\begin{array}{l}\text { TNF secretion }(\mathrm{ng} / \mathrm{L}) \text { by } \\
\text { CBMO }(6 \mathrm{~h})\end{array}$ \\
\hline $\begin{array}{l}\text { Medium only } \\
3.7 \times 10^{-4} \mathrm{M}(0.1 \mathrm{~g} / \mathrm{L}) \mathrm{Fc} \\
2.0 \times 10^{-6} \mathrm{M}(0.1 \mathrm{~g} / \mathrm{L}) \mathrm{Fab} \\
9.1 \times 10^{-7} \mathrm{M}(0.1 \mathrm{~g} / \mathrm{L}) \mathrm{F}\left(\mathrm{ab}^{\prime}\right)_{2} \\
3.7 \times 10^{-3} \mathrm{M}(1 \mathrm{~g} / \mathrm{L}) \mathrm{Fc} \\
2.0 \times 10^{-5} \mathrm{M}(1 \mathrm{~g} / \mathrm{L}) \mathrm{Fab} \\
9.1 \times 10^{-6} \mathrm{M}(1 \mathrm{~g} / \mathrm{L}) \mathrm{F}\left(\mathrm{ab}^{\prime}\right)_{2}\end{array}$ & $\begin{aligned} 1224.4 & \pm 529.3 \\
1457.0 & \pm 957.4 \\
1632.2 & \pm 684.8 \\
3003.1 & \pm 2024.6 \dagger \\
2134.0 & \pm 2432.3 \\
780.2 & \pm 411.4 \\
3520.0 & \pm 2534.2 \dagger\end{aligned}$ \\
\hline
\end{tabular}

\footnotetext{
* Monocytes isolated as described in Materials and Methods were preincubated with 0.1 or $1 \mathrm{~g} / \mathrm{L} \mathrm{Fc}$, Fab, or $F\left(\mathrm{ab}^{\prime}\right)_{2}$ fragments. After $6 \mathrm{~h}$, monolayers were replated with IFN- $\gamma\left(10^{5} \mathrm{U} / \mathrm{L}\right)$ and $\mathrm{LPS}(1 \mathrm{mg} / \mathrm{L})$. After a 3-h incubation in these stimulants, TNF concentration in the supernatant was determined by ELISA. Results are means \pm SD of 10 experiments for all except "Medium only" and $\mathrm{F}\left(\mathrm{ab}^{\prime}\right)_{2}$, where $n=15$. $+p<0.05$.
}

series for both prophylaxis and treatment of sepsis, we initially sought to address the question of the ability of $\mathrm{IgG}$ to induce TNF production by neonatal MO. We demonstrated that the addition of soluble IgG to adherent CBMO is not a sufficient stimulus to generate the production of TNF (Table 1, Fig. 1). This was true for adult MO as well; we demonstrated that the lack of response is not due to a deficiency inherent to the neonate. In addition, all experiments were performed in monocyte-derived macrophages that were cultured for $5 \mathrm{~d}$. Time in culture allows for the development of Fc $\gamma$ RIII expression, in addition to the constitutive expression of $\mathrm{Fc} \gamma \mathrm{RI}$ and $\mathrm{Fc} \gamma \mathrm{RII}$. Fc $\gamma$ RIII develops on monocytes in vitro after $2 \mathrm{~d}$ of culture (38), although recently it was discovered that a subpopulation $(\sim 10 \%)$ of freshly isolated monocytes expresses Fc $\gamma$ RIII (39). Thus, in our system, the potential exists for IgG to interact with any or all three of the Fc $\gamma$ R. Kuhnert et al. (14) used $10 \%$ autologous serum in their experiments and proposed that dimeric IgG generated by idiotype-antiidiotype complexes between donor and host IgG or between IgG molecules from different donors are a possible mechanism whereby IVIG promotes cytokine synthesis. Our experiments used $10 \%$ pooled human $\mathrm{AB}$ serum and concentrations of IVIG that are comparable to those seen in vivo $(22,40)$. The obvious difference between our experiments and those performed by Kuhnert et al. (14) is that we used MO cultured as adherent monolayers rather than as suspended cells. It is possible that the act of adherence inhibited the induction of TNF by IgG. The prolonged contact of monocytes with polystyrene can inhibit other FcR-mediated functions, such as phagocytosis of opsonized erythrocytes (41). Evidence against inhibition of TNF production by adherence lies in the positive results of the studies of Debets et al. $(12,13)$. Furthermore, we have previously shown that the act of adherence turns on various cytokine genes in MO, including the gene for TNF (42).

Kuhnert et al. (14) demonstrated that IgG exposure primed suspended mononuclear cells for enhanced cytokine production in a second $24-\mathrm{h}$ culture with LPS. We demonstrated a similar priming phenomenon with adherent MO. Neonatal CBMO and adult MO, when exposed to IgG in concentrations of $1-25 \mathrm{~g} / \mathrm{L}$, exhibited enhanced secretion of TNF upon subsequent stimulation with IFN- $\gamma$ /LPS (Tables 2 and 3). In the absence of IgG preincubation, CBMO secreted significantly less TNF in response to IFN- $\gamma /$ LPS stimulation when compared with adult MO. Similar findings were reported by Burchett et al. (43). They demonstrated that, although freshly isolated CBMO secreted TNF in amounts similar to adults when stimulated with LPS, cultured neonatal monocyte-derived macrophages as well as fetal placental macrophages secreted less TNF than adult cells. In addition, IFN- $\gamma$ enhanced LPS-induced TNF production by neonatal cells less effectively than it enhanced that by adult cells. Burchett $e t$ al. (43) proposed that a combined deficiency of neonatal lymphocyte IFN- $\gamma$ production with a decreased macrophage response to IFN- $\gamma$ may lead to relatively decreased secretion of TNF by neonatal tissue macrophages. The results of our study indicate that exposure of neonatal MO to $\mathrm{IgG}$ may augment their TNF secretion in response to IFN- $\gamma / \mathrm{LPS}$ exposure to levels that approach those seen in adults. The absence of an enhanced response by CBMO when lower concentrations of $\mathrm{IgG}$ were used for preincubation $\left[6.3 \times 10^{-8} \mathrm{M}\right.$ and $6.3 \times 10^{-7} \mathrm{M}(0.1$ and 0.01 $\mathrm{g} / \mathrm{L})]$ indicates a dose dependency for the mechanism of augmentation (Table 3).

Northern analyses of mRNA for TNF indicated that the increased TNF response mediated by IgG primarily occurred posttranscriptionally (Fig. 2). Although preincubation of $\mathrm{MO}$ in 1 and $10 \mathrm{~g} / \mathrm{L} \mathrm{IgG}$ resulted in significant increases in the secretion of TNF, levels of TNF mRNA were unchanged. These concentrations of IgG may act to enhance translation of TNF mRNA in response to IFN- $\gamma / \mathrm{LPS}$ stimulation or by improving posttranslational processing and secretion of the protein. When $\mathrm{MO}$ were preincubated in $25 \mathrm{~g} / \mathrm{L} \mathrm{IgG}$, slight augmentation of the MO TNF response occurred at the pretranslational level $(\sim 2$-fold increase 
in mRNA for TNF). This increase in mRNA for TNF could be caused by enhanced mRNA stability or by an increase in transcription.

Data supporting a posttranscriptional mechanism for augmentation come from experiments in which CBMO were first incubated in the stimulants IFN- $\gamma /$ LPS for $18 \mathrm{~h}$, then incubated in either medium alone or medium with $10 \mathrm{~g} / \mathrm{L} \mathrm{IgG}$ for $6 \mathrm{~h}$. The addition of IgG allowed for continued detection of TNF $(602.2$ $\pm 243.7 \mathrm{ng} / \mathrm{L}$ ), whereas in cells replated with medium alone the TNF levels were minimal $(59.9 \pm 34.6 \mathrm{ng} / \mathrm{L})$. IFN- $\gamma$ combined with LPS, in the concentrations used in our study, has been shown to induce transcription of TNF mRNA at near maximal levels (44). In addition, studies indicate that once the TNF gene is transcriptionally active posttranscriptional mechanisms operate to control TNF gene expression $(45,46)$. Therefore, the ability of IgG to induce an enhanced response in the face of prior stimulation with IFN- $\gamma$ /LPS suggests that the entire effect of IgG demonstrated in our study is most likely posttranscriptionally mediated.

Several mechanisms could be acting to produce this effect. The potential exists for antibodies present in the IVIG to bind to LPS and form IgG/LPS immune complexes that could act as a potent stimulus for TNF production in vitro. Interestingly, when CBMO were incubated in IgG and IFN- $\gamma /$ LPS simultaneously for $3 \mathrm{~h}$, no significant increase in TNF secretion was detected compared with cells incubated in IFN- $\gamma /$ LPS alone. Thus, it seems unlikely that IgG/LPS complexes are the stimulus for enhanced TNF production in our studies. A 2-h preincubation in IgG before a 3-h incubation in IFN- $\gamma /$ LPS resulted in a significant increase in TNF secretion compared with CBMO preincubated in medium alone. These data indicate that a minimum amount of time must be present for IgG to interact with the MO and produce the signals necessary for an enhanced response.

To further explore the mechanism whereby IgG enhances IFN$\gamma /$ LPS-induced TNF production, experiments were performed with the $F c$, Fab, and $F\left(a b^{\prime}\right)_{2}$ fragments of IgG. Only the $F\left(a b^{\prime}\right)_{2}$ fragments were able to produce an enhanced response, which did not reach the levels seen with whole $\mathrm{IgG}$ molecules. These results indicate involvement of the $\mathrm{F}\left(\mathrm{ab}^{\prime}\right)_{2}$ portion of $\mathrm{IgG}$. It should be noted that all our experiments were performed in $10 \%$ pooled human $A B$ serum containing significant amounts of IgG. The results of our study also indicate a concentration dependence of this enhanced response, with $25 \mathrm{~g} / \mathrm{L} \mathrm{IgG}$ consistently producing the maximum increase in TNF secretion and no increase in TNF secretion being detected when concentrations of $\mathrm{IgG}$ below $1 \mathrm{~g} / \mathrm{L}$ were used with CBMO.

Another potential mechanism is that exposure of MO to IFN- $\gamma$ leads to up-regulation of Fc $\gamma$ RI (47), which then binds IgG through its Fc region, leading to high levels of IgG-FcR interaction that stimulate pathways that augment the TNF response. However, this does not explain the positive effects of $\mathrm{F}\left(\mathrm{ab}^{\prime}\right)_{2}$ fragments.

Interaction of $F c \gamma R$ with immune complexes has been shown to trigger release of a variety of soluble mediators. Debets et al. (13) demonstrated that MO FcR cross-linking was necessary but not sufficient for the induction of TNF by IgG; no response was seen with the use of anti-FcR MAb and bridging antibody. In our system, enumerable IgG idiotopes exist; IgG is present from host, from serum that is used for culture, and from more than 10000 donors in the IVIG. Perhaps the formation of idiotypeantiidiotype complexes between the multiple sources of $\mathrm{IgG}$, or between the multiple sources of IgG and $F\left(a b^{\prime}\right)_{2}$ fragments, leads to cross-linking of some $\mathrm{FcR}$ and binding of others through the Fc region of IgG. Higher concentrations of IVIG would increase the chance for such processes to occur. These interactions are obviously not sufficient to stimulate TNF release by themselves but are able to augment stimulatory pathways.

A fourth hypothesis is that alloantibodies react with MO surface antigens, thereby promoting cell activation. IL-1 is in- duced in human monocytes exposed to antibodies against Ia antigens (48). Alloantibodies directed against immunoglobulin allotopes might also function to produce immune complex formation, thereby promoting cell stimulation. It is also possible that no single mechanism is responsible for the increase in TNF production, but that several different IgG-MO interactions combine to produce the observed response.

The absence of a TNF response by MO cultured in the presence of IVIG in vitro lends support to the continued use of IVIG as replacement therapy for neonates, as well as for other patients with hypogammaglobulinemia. It has been proposed that the interaction of MO with IVIG dampens the cytokine response to other unrelated stimuli (49). Indeed, IVIG has been shown to be clinically beneficial in patients with Kawasaki disease (40) and infection-associated hemophagocytic syndrome (50), conditions associated with cytokine activation. In addition, multiple treatment studies in neonates with sepsis have not demonstrated any toxic effects associated with IVIG administration (15-19). The enhanced TNF response detected from MO cultured in the presence of IgG and stimulated with IFN- $\gamma /$ LPS in vitro is not consistent with these in vivo observations. Several possibilities exist for this discrepancy. Our studies examined isolated populations of $\mathrm{MO}$, whereas in vivo multiple inflammatory cells and their products interact in a complex manner to control cytokine production. It is also possible that IgG elicits different responses when interacting with blood monocytes in the peripheral circulation than when interacting with adherent macrophages in the tissues.

In at least two animal models of established infection, infusion of $\mathrm{IgG}$ in addition to antibiotics has been found to be detrimental, resulting in increased mortality rates $(51,52)$. Both these studies used high doses of IVIG in rats, indicating that deleterious effects may not be seen unless high in vivo concentrations of IgG are produced. These animal studies support the detection of a lower threshold concentration in our present in vitro studies. The immunomodulating effects of IVIG are complex and include Fc receptor blockade, antiidiotype effects, and possibly down-regulation of immunoglobulin synthesis. The data presented here are further indications of the complex network of responses that exist to control the inflammatory response.

Acknowledgment. The authors thank Christopher B. Wilson, M.D., for his critical review of this manuscript.

\section{REFERENCES}

1. Nathan CF 1987 Secretory products of macrophages. J Clin Invest 79:319-326

2. Tracey KJ, Beutler BA, Lowry SF 1986 Shock and tissue injury induced by recombinant human cachectin. Science 234:470-474

3. Mellman IS, Plutner H, Steinman RM, Unkeless JC, Cohn ZA 1983 Internal. ization and degradation of macrophage $\mathrm{Fc}$ receptors during receptor-mediated phagocytosis. J Cell Biol 96:887-895

4. Graziano RF, Fanger MW 1987 Human monocyte-mediated cytotoxicity: the use of Ig-bearing hybridomas as target cells to detect trigger molecules on the monocyte cell surface. J Immunol 138:945-950

5. Michl J, Unkeless JC, Pieczonka MM, Silverstein SC 1983 Modulation of Fc receptors by immobilization antigen-antibody complexes. Quantitative analysis of the relationship between ligand number and Fc receptor response. J Exp Med 157:1746-1757

6. Passwell JH, Dayer JM, Merher E 1980 Regulation by Fc fragments of the secretion of collagenase, $\mathrm{PGE}_{2}$, and lysozyme by mouse peritoneal macrophages. J Immunol 125:910-913

7. Rouzer CA, Scott WA, Hamill AL, Cohn A 1980 Dynamics of leukotriene C production by macrophages. Proc Natl Acad Sci USA 152:1236-1247

8. Rouzer CA, Scott WA, Kempe J, Cohn ZA 1980 Prostaglandin synthesis by macrophages requires a specific receptor-ligand interaction. Proc Natl Acad Sci USA 77:4279-4282

9. Cardella CJ, Daries P, Allison AC 1974 Immune complexes induce selective release of lysosomal hydrolases from macrophages. Nature 247:46-48

10. Anegon I, Cuturi ME, Trincheieri G, Perussia B 1988 Interaction of Fc receptor (CD16) ligands induces transcription of interleukin 2 receptor (CD25) and lymphokine genes and expression of their products in human natural killer cells. J Exp Med 167:452-472

11. Krutmann J, Kirkbauer R, Kock A, Schwarz T, Schopf E, May LT, Schgal PB, Luger TA 1990 Cross-linking Fc receptors on monocytes triggers IL-6 production. J Immunol 145:1337-1342 
12. Debets JMH, Van der Linden CJ, Dieteren IEM, Leeuwenberg JFM, Buurman WA 1988 Fc-receptor cross-linking induces rapid secretion of tumor necrosis factor (cachectin) by human peripheral blood monocytes. J Immuno 141:1197-1201

13. Debets JMH, van de Winkel JGJ, Ceuppens JL, Dieteren IEM, Duurman WA 1990 Cross-linking of both Fc $\gamma$ RI and Fc $\gamma$ RII induces secretion of tumor necrosis factor by human monocytes requiring high affinity Fc-Fc $\gamma R$ interactions. J Immunol 144:1304-1310

14. Kuhnert P, Schalch L, Jungi TW 1990 Cytokine induction in human mononuclear cells stimulated by $\lg$ G-coated culture surfaces and by $\lg G$ for infusion. Clin Immunol Immunopathol 57:218-232

15. Sideropoulos D, Boehme U, Von Muralt G 1981 Immunoglobulin supplementation in the management of neonatal sepsis. Schweiz Med Wochenschr 111:1649-1655

16. Haque KN, Zaidi MH, Bahakim H 1988 IgM-enriched intravenous immunoglobulin therapy in neonatal sepsis. Am J Dis Child 142:1293-1296

17. Friedman CA, Wender DF, Temple DM 1990 Intravenous gamma globulin as adjunct therapy for severe group B streptococcal disease in the newborn. Am J Perinatol 7:1-4

18. Christensen RD, Brown MS, Hall DC, Lassiter HA, Hill HR 1991 Effect on neutrophil kinetics and serum opsonic capacity of intravenous administration of immune globulin to neonates with clinical signs of early-onset sepsis. J Pediatr 118:606-614

19. Weisman LE, Stoll BJ, Kueser TJ, Rubio TT, Frank G, Heiman HS 1992 Intravenous immune globulin for early-onset sepsis in premature neonates. J Pediatr 121:434-443

20. Clapp DW, Kliegman RM, Baley JE 1989 Use of intravenously administered immune globulin to prevent nosocomial sepsis in low birth weight infants: report of a pilot study. J Pediatr 115:973-978

21. Bussel JB 1990 Intravenous gammaglobulin in the prophylaxis of late sepsis in very-low-birth-weight infants: preliminary results of a randomized, doubleblind placebo-controlled trial. Rev Infect Dis 12(suppl 4):S457-S462

22. Baker CJ, Melish ME, Hall RT 1992 Intravenous immune globulin for the prevention of nosocomial infection in low-birth-weight-neonates. $\mathrm{N}$ Engl J Med 327:213-219

23. Kinney J, Mundorf L, Gleason C 1991 Efficacy and pharmacokinetics of intravenous immune globulin administration to high-risk neonates. Am J Dis Child 145:1233-1238

24. Magny J-F, Bremard-Oury C, Brault D 1991 Intravenous immunoglobulin therapy for prevention of infection in high-risk premature infants: report of a multicenter, double-blind study. Pediatrics 88:437-443

25. Fanaroff A, Wright E, Korones S, Wright L 1992 A controlled trial of prophylactic intravenous immunoglobulin (IVIG) to reduce nosocomial infections (N.I.) in VLBW infants. Pediatr Res 31:202A(abstr)

26. Siber GR 1992 Immune globulin to prevent nosocomial infections. N Engl J Med 327:269-27

27. Zlabinger GJ, Mannhalter JW, Eibl MM 1983 Cord blood macrophages present bacterial antigen (Escherichia coli) to paternal T cells. Clin Immunol Immunopathol 28:405-412

28. Orlowski JP, Sieger L, Anthony BF 1976 Bactericidal capacity of monocytes of newborn infants. J Pediatr 89:797-801

29. Rahunathan R, Miller ME, Everett S 1982 Phagocyte chemotaxis in the perinatal period. J Clin Immunol 2:242-246

30. Klein RB, Fischer TJ, Gard SE 1977 Decreased mononuclear and polymorphonuclear chemotaxis in human newborns, infants, and young children. Pediatrics 60:467-472

31. Kohl S, Loo S, Gonik B 1984 Analysis in human neonates of defective antibody-dependent cellular cytotoxicity and natural killer cytotoxicity to herpes simplex virus-infected cells. J Infect Dis 150:14-19

32. Adams DO, Edelson PJ, Koren HS 1981 Methods for Studying Mononuclear Phagocytes. Academic Press, New York, pp 8-11
33. Carswell EA, Old LJ, Kassell RI, Green S, Fiore N, Williamson B 1975 An endotoxin-induced serum factor that causes necrosis of tumors. Proc Natl Acad Sci USA 72:3666-3670

34. Agoarwal BB, Kohr WJ, Hass PE, Moffat B, Nedwin GE, Goeddel DV, Harkins RN 1985 Human tumor necrosis factor. Production, purification, and characterization. J Biol Chem 260:2345-2354

35. Maniatis T, Fristch EF, Sambrook J 1982 Extraction, purification, and analysis of mRNA from eukaryotic cells. In: Molecular Cloning: A Laboratory Manual. Cold Spring Harbor Laboratory Press, Cold Spring Harbor, pp 196204

36. Pennica D, Nedwin GE, Hayflick JS, Seeburg PH, Derynck R, Palladino MA, Kohr WJ, Aggarwal BB, Goedel DV 1984 Human tumor necrosis factor: precursors structure, expression, and homology to lymphotoxin. Nature 312:724-728

37. Shimozato T, Iwata M, Tamura N 1990 Suppression of tumor necrosis factor alpha production by a human immunoglobulin preparation for intravenous use. Infect Immun 58:1384-1390

38. Clarkson SB, Ory PA 1988 CD16. Developmentally regulated IgG Fc receptors on cultured human monocytes. J Exp Med 167:408-420

39. Passlick B, Flieger D, Sieglre-Heitbrock HWL 1989 Identification and characterization of a novel monocyte subpopulation in human peripheral blood. Blood 74:2527-2534

40. Newburger JW, Takahashi M, Beiser AS, Burns JC, Bastian J, Chung KJ 1991 A single intravenous infusion of gamma globulin as compared with four infusions in the treatment of acute Kawasaki Syndrome. N Engl J Med 324:1633-1639

41. Jungi TW, Von Below G, Lerch PG, Spaeth PJ 1987 Modulation of human monocyte Fc receptor function by surface-absorbed IgG. Immunology 60:261-268

42. Darville T, Tabor DR, Theus SA, Jacobs RF 1992 Surface matrix binding alters murine peritoneal mononuclear phagocyte TNF- $\alpha$ and IL-6 induction. Immunol Invest 21:539-552

43. Burchett SK, Weaver WM, Westall JA, Larsen A, Kronheim S, Wilson CB 1988 Regulation of tumor necrosis factor/cachectin and IL-1 secretion in human mononuclear phagocytes. J Immunol 140:3473-3481

44. Yu SF, Koerner TJ, Adams DO 1990 Gene regulation in macrophage activation differential regulation of genes encoding for tumor necrosis factor, interleukin-1, JE, and $\mathrm{KC}$ by interferon- $\gamma$ and lipopolysaccharide. J Leukoc Biol 48:412-419

45. Han J, Brown T, Beutler B 1990 Endotoxin-responsive sequences control cachectin/tumor necrosis factor biosynthesis at the translational level. J Exp Med 171:465-475

46. Sariban E, Imamura K, Luebbers R, Kufe D 1988 Transcriptional and posttranscriptional regulation of tumor necrosis factor gene expression in human monocytes. J Clin Invest 81:1506-1510

47. Perussia B, Dayton ET, Lazarus R, Fanning V, Trinchieri G 1983 Immune interferon induces the receptor for monomeric IgGl on human monocytic and myeloid cells. J Exp Med 158:1092-1113

48. Palacios $R 1985$ Monoclonal antibodies against human la antigens stimulate monocytes to secrete interleukin-1. Proc Natl Acad Sci USA 82.6652-6656

49. Dwyer JM 1992 Manipulating the immune system with immune globulin. $N$ Engl J Med 326:107-116

50. Freeman B, Rathore MH, Salman E, Joyce MJ, Pitel P 1993 Intravenously administered immune globulin for the treatment of infection associated hemophagocytic syndrome. J Pediatr 123:479-481

51. Schreiber RJ, Basker C, Priehs C, Siber G 1987 Deleterious effect of immune globulin in the treatment of $\boldsymbol{H}$. influenzae B infection in infant rats. Pediatr Res 21:334A(abstr)

52. Kim KS 1987 Efficacy of human immunoglobulin and penicillin $G$ in treatment of experimental group B streptococcal infection. Pediatr Res 21:289292 